Research Paper:

\title{
Assessment of Human Health Risk and Surface Soil Con- tamination by Some Toxic Elements in Arak City, Iran
}

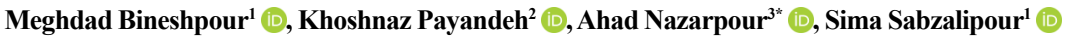

1. Department of Environment, Ahvaz Branch, Islamic Azad University, Ahvaz, Iran

2. Department of Soil Sciences, Ahvaz Branch, Islamic Azad University, Ahvaz, Iran.

3. Department of Geology, Ahvaz Branch, Islamic Azad University, Ahvaz, Iran.

\begin{tabular}{|c|c|}
\hline $\begin{array}{l}\text { Use your devicet toscan } \\
\text { and read the article online }\end{array}$ & \\
\hline 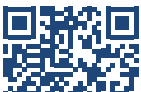 & $\begin{array}{l}\text { Contamination by Some Toxic Elements in Arak City, Iran. Journal of Advances in Environmental Health Research. 2021; } \\
\text { (4) } 3 \text {; } 32 \text {. http://dx.doi.org/10.32598/JAEHR.9.4.1233 }\end{array}$ \\
\hline 口ffing & doi : http://dx.doi.org/10.32598/JAEHR.9.4.1233 \\
\hline
\end{tabular}

\section{(i)}

Article info:

Received: 23 Jun 2021

Accepted: 25 Aug 2021

Publish: 01 Oct 2021

\section{Keywords:}

Arak, Toxic elements, Pollution indicators,

Health assessment

\section{A B S T R A C T}

Background: Population growth, numerous factories, and many vehicles are the primary sources of environmental pollution and toxic elements in the industrial city of Arak, Iran.

Methods: In June 2016, a total of 30 toxic element samples were taken from surface soils to examine their contents of lead (Pb), Zinc ( $\mathrm{Zn})$, Copper $(\mathrm{Cu})$, Nickel $(\mathrm{Ni})$, Arsenic (As), Chromium (Cr), and Cadmium (Cd). The samples were collected from 0 to $20 \mathrm{~cm}$ depth and measured using Atomic Absorption Spectroscopy (AAS) (PG990 Model).

Results: The results showed that the mean concentrations of all toxic elements except arsenic had a higher value than the background values in the world. The Top Enrichment Factor (TEF) of toxic elements of nickel, chromium, lead, and copper was higher than other elements. The Potential Ecological Risk (PER) index showed high and very high risk for the elements. For all elements, the Hazard Index (HI) values were higher for children than for adults. Moreover, the results of carcinogenic health risk assessment (Carcinogenicity Risk [CR]) of the toxic elements for $\mathrm{Cr}$ in children with an average value of 0.001 and adults with an average value of 3.81e-04 showed that the $\mathrm{CR}$ of chromium for children poses a serious threat to the health of children and adults.

Conclusion: In general, the toxic element pollution for the surface soil of Arak is of concern, and significant measures should be taken to reduce the pollutants.

\footnotetext{
* Corresponding Author:

Ahad Nazarpour, PhD.

Address: Department of Geology, Ahvaz Branch, Islamic Azad University, Ahvaz, Iran.

Phone: +98 (916) 7729443

E-mail:ahad.nazarpour@gmail.com; a.nazarpour@iauahvaz.ac.ir
} 


\section{Introduction}

$\mathbf{I}$

$\mathrm{n}$ general, pollution sources of toxic elements in soil include geogenic (weathering of earth materials) and anthropogenic (accumulation of toxic elements from industrial areas, disposal of element waste, gasoline and lead, pesticides, chemical fertilizers, atmospheric sedimentation, coal combustion residues, etc.) [1]. These pollutants are transferred from fixed and mobile sources to water, soil, and air and then to plants, animals, and the human body. They can also accumulate in the urban, plant, soil, and building surfaces and then be transferred to various locations by natural and human forces [2]. Toxic element pollution in agricultural soils disrupts soil yield and plant growth and harms human health through food chain contamination. With the accumulation of toxic elements in living organisms and their concentrations when passing through the nutrientpoor organism, the nutrition content increases, leading to well-known phenomena like biological concentration [3]. A study conducted by Moghtaderi et al. [2] investigated the pollution assessment, health risk, and ecological risk index of potentially toxic elements in the soil surface of the central part of Bandar Abbas Port, Iran. The results showed that the mean ecological risk indicated a moderate and high risk for copper $(\mathrm{Cu})$ and Cadmium (Cd) [4]. In another study, Dolezalova Weissmannova et al. [5] investigated the contamination of toxic elements of cadmium, lead $(\mathrm{Pb})$, Zinc ( $\mathrm{Zn})$, copper, Manganese $(\mathrm{Mn})$, Vanadium $(\mathrm{Vi})$, and mercury $(\mathrm{Hg})$ in urban soils in Ostrava, Czech Republic, and evaluated element pollution and principal component analysis. The results of the element pollution assessment showed that urban soils were moderate to strongly polluted. Zhuo et al. [6] also reviewed the source analysis and risk assessment of toxic elements in Rizhao, China. Their results showed that many toxic elements have accumulated in developing areas. Therefore, this study aimed to evaluate the pollution caused by the toxic elements of $\mathrm{Pb}, \mathrm{Zn}, \mathrm{Cu}$, Nickel (Ni), Arsenic (As), Chromium (Cr), and Cd in the soil surface of Arak City, Iran, using the pollution indices of Muller geo-accumulation index (Igeo), Top Enrichment Factor (TEF), Pollution Index (PI), and Nemerow Integrated Pollution Index (NIPI). In addition, human health risk assessment was performed using the Carcinogenicity Risk (CR) and non-carcinogenicity risk (HI) indices. Soil pollution with toxic elements is one of the essential types of pollutants. They are classified as the most dangerous group in terms of toxicity and stability. Also, they are of great ecological and biological importance due to their soil pollution characteristics, toxicity, long residence time, and accumulation in the tissues of organisms. Toxic elements present in the soil are absorbed by plants and enter the food chain and endanger the health of living organisms by entering groundwater and surface water. Therefore, the irreversible effects of toxic element accumulation on human health and other living organisms should be considered. For this purpose, we examined the extent of soil pollution in Arak and the risk results on the extent of human health using various indicators that are the innovation of this study.

\section{Materials and Methods}

\section{Sampling and sample analysis}

Sampling sites were selected based on pollutant entry points (pollution hotspots) and their proximity to pollutant sources and industrial sites. A total of 30 sampling sites were established in the study area for soil sampling in June 2016 (Figure 1). Soil sampling was performed using a plastic shovel from a depth of $6 \mathrm{~cm}$ at each station, except for the last station, which was at a depth of $20 \mathrm{~cm}$. The collected soil samples were then placed in plastic containers and transferred to the laboratory. The reason for selecting 30 stations was to cover the entire area, including urban, industrial, and agricultural areas. The well-known manufacturing industries in this region include Iranian Aluminum Company, Train Center, Heavy Equipment Production Company, Azarab Industries Company, Arak Industrial hub, Wagon Pars Company, and Rolled Aluminum Group. The surface soil samples were collected from high-traffic areas, city squares, main streets, industrial and residential areas, sidewalks, and paved roads. To study the concentration of toxic element pollutants in the surface soils of Arak, we performed sampling and measurements with standard methods presented in the published papers [7,8]. Finally, the toxic element samples (including $\mathrm{Zn}, \mathrm{Cr}$, As, $\mathrm{Cu}, \mathrm{Cd}, \mathrm{Pb}$, and $\mathrm{Ni}$ ) were measured using Atomic $\mathrm{Ab}-$ sorption Spectroscopy (AAS) (PG990 Model) in Islamic Azad University of Ahvaz. Statistical analysis of the data was performed in Excel and SPSS. Also, the calculation of indices and the preparation of distribution maps of the toxic elements studied were performed by the inverse distance weighting method in Excel and ArcGIS v. 10.7 software, respectively.

\section{Evaluation of toxic element pollution}

In this study, we used Igeo, TEF, and NIPI to evaluate toxic element pollution. The Igeo index determines the degree of soil pollution, calculated according to Equation 1 [9]. 


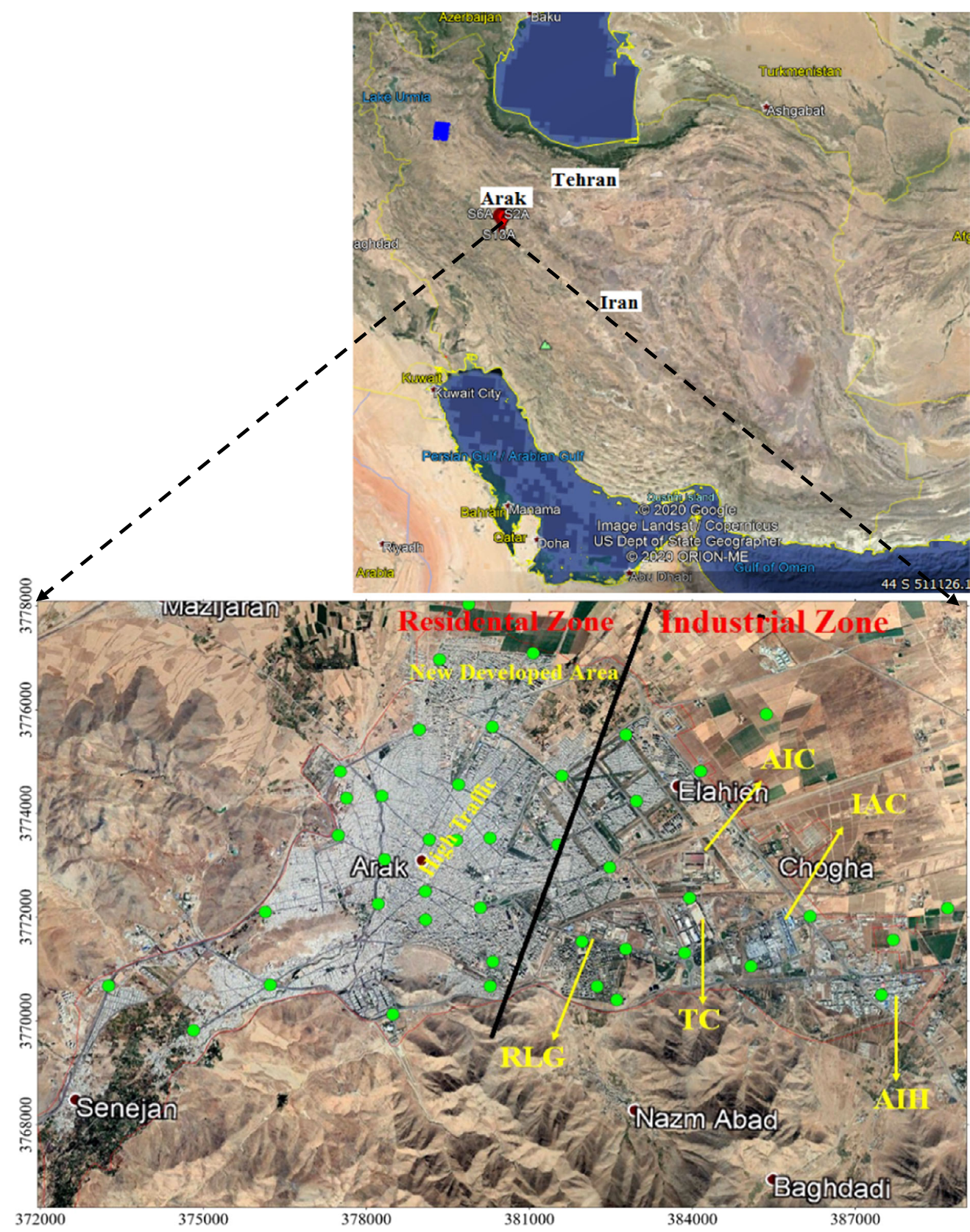

Figure 1. Sampling sites and location of large industries in arak

$$
\text { 1. } \operatorname{IgeO}=\log _{2}\left[\frac{C n}{B n \times 1.5}\right]
$$

Igeo: Geo-accumulation index

$\mathrm{Cn}$ : Concentration of studied element in soil samples or sediment.

Bn: Concentration of element (element) studied in background value or Earth crust (average global shale). Also, 1.5 is the shale correction factor in removing the impact of lithology [10].
In this study, the concentrations of elements in the Earth crust are given in $\mathrm{mg} / \mathrm{kg}$, including $\mathrm{Pb}(14), \mathrm{Zn}$ (70), $\mathrm{Cu}$ (60), Ni (84), As (1.8), Cr (102), and Cd (0.15) [11]. Table 1 presents the pollution intensity of Igeo.

Equation 2 was used to estimate the percentage of geogenic resources from the anthropogenic form of toxic elements, especially for elements with a mixture of geogenic and anthropogenic sources [12]

$$
\text { 2. \%Anthro }=\frac{\left\{\left(\left(\left[M_{\text {total }}\right]\right)-\left(\left[A l_{\text {sample }}\right]\left(\left(\frac{[M]}{[A l]}\right)_{\text {reference }}\right)\right)\right\}\right.}{[M]_{\text {total }}} \times 100
$$


Table 1. Classification of geo-accumulation index based on pollution intensity

\begin{tabular}{ccc}
\hline Class & Range & Pollution Intensity \\
\hline 0 & $0>$ geo & Unpolluted \\
\hline 1 & $0<$ Igeo $<1$ & Unpolluted to moderately polluted \\
2 & $1<$ geo $<2$ & Moderately polluted \\
3 & $2<$ geo $<3$ & Moderately to strongly polluted \\
4 & $3<$ geo $<4$ & Strongly polluted \\
\hline 5 & $4<$ Igeo $<5$ & Strongly to extremely polluted \\
\hline 6 & Igeo $>5$ & Extremely polluted \\
\hline
\end{tabular}

$\left[\mathrm{M}_{\text {total }}\right]$ and $[\mathrm{M}]$ represent the total concentration $(\mathrm{mg} /$ $\mathrm{kg}$ ) of the target element in the soil sample and reference material (UCC), respectively. $\mathrm{Al}_{\text {sample }}$ and $\mathrm{Al}_{\text {Reference }}$ are the concentrations of $\mathrm{Al}$ in the soil sample and reference material, respectively. $\mathrm{Al}_{\text {sample }}$ and $\mathrm{Al}_{\text {Reference }}$ indicate the amount of aluminum concentration in the soil sample and reference material, respectively. The Pollution Index (PI) was used to determine the pollution rate of toxic elements in the studied surface soils (Equation 3).

$$
\text { 3. } P I=\frac{C_{n}}{B_{N}}
$$

$\mathrm{Cn}$ : Concentration of element or element measured in the soil sample.

Bn: Concentration of element or element measured in background value or Earth crust. This value is expressed for elements when calculating the Igeo index [13]. Table 2 presents the PI classification in four classes [14].

The NIPI index is calculated to determine pollution. The advantage of this index over other indicators is that this index determines the pollution risk for all elements studied in the region. The NIPI is calculated according to Equation 4 at each sampling point.

$$
\text { 4. } N I P I=\sqrt{\frac{P \operatorname{Imax}^{2} P I_{a v e}^{2}}{2}}
$$

$\mathrm{PI}_{\max }$ is the maximum pollution index for each toxic element, and $\mathrm{PI}_{\text {ave }}$ is the average pollution index for each toxic element [15]. Table 3 presents the classification of the NIPI index in five classes [16].

Hakanson presented the potential ecological risk index in 1980. By applying the toxicity of each element and its accumulation in the study area, this index gives a picture of the risk conditions in the region. According to this method, the potential ecological risk index of a single element $\left(\mathrm{E}_{\mathrm{r}}^{\mathrm{i}}\right)$ and the comprehensive potential ecological Risk Index (RI) can be calculated by the Equations 5, 6 and 7:

$$
\begin{aligned}
& \text { 5. } C_{f}^{i}=C_{D}{ }^{i} / C_{R}{ }^{i} \\
& \text { 6. } E_{r}^{i}=T_{r}^{i} \times C_{f}^{i} \\
& \text { 7. } R I=\sum^{n}{ }_{i=1} E_{r}^{i}
\end{aligned}
$$

$C_{f}^{i}$ is the contamination factor; $C_{D}{ }^{i}$ is the concentration of each toxic element in the sewage sludge ash; $C_{R}{ }^{i}$ is the background value of individual toxic elements and defined as Bn. $E_{r}^{i}$ is the toxic response factor of each toxic element and $T_{r}^{i}$ is the potential ecological risk index of the toxic element. RI is the comprehensive potential ecological risk index [17]. The toxicity factors of the studied elements are as follows: $\mathrm{Cd}=1, \mathrm{Cr}=2, \mathrm{~Pb}=5, \mathrm{Zn}=1$, $\mathrm{Cu}=5, \mathrm{As}=10$, and $\mathrm{Ni}=5$. Table 4 presents the classifica-

Table 2. Classification of Pollution Index (PI)

\begin{tabular}{ccc}
\hline Class & Range & Pollution Intensity \\
\hline 1 & $\mathrm{PI} \leq 1$ & Unpolluted \\
2 & $1 \leq \mathrm{Pl}<3$ & Slightly polluted \\
3 & $3 \leq \mathrm{PI}<5$ & Moderately polluted \\
4 & $\mathrm{Pl}>5$ & Strongly polluted \\
\hline
\end{tabular}


Table 3. Classification of NIPI index

\begin{tabular}{cccc}
\hline Class & Range & Pollution Intensity \\
\hline 1 & $\mathrm{NIPI} \leq 0.7$ & No pollution \\
2 & $0.7 \leq \mathrm{NIPI}<1$ & Risk of pollution & Low pollution level \\
3 & $1 \leq \mathrm{NIPI}<2$ & Moderate pollution level \\
4 & $2 \leq \mathrm{NIPI}<3$ & High pollution level \\
\hline
\end{tabular}

tion presented for the RI index of potential ecological risk for the total elements.

\section{Human health risk assessment}

To investigate carcinogenic and non-carcinogenic risks, human exposure to elements by all three routes, namely ingestion, inhalation, and dermal absorption, was considered. The Average Daily Dose (ADD) was also calculated in $\mathrm{mg} / \mathrm{kg} /$ day for adults and children by each route according to Equations 8, 9, and 10 [18]. The $\mathrm{C}$ parameter is the concentration of elements in the soil in $\mathrm{mg} / \mathrm{kg}$.

$$
\begin{aligned}
& \text { 8. } A D D_{\text {ing }}=\frac{C \times I n g R \times C F \times E F \times E D}{B W \times A T} \\
& \text { 9. } A D D_{\text {inh }}=\frac{C \times I n g R \times C F \times E F \times E D}{P E F \times B W \times A T} \\
& \text { 10. } A D D_{\text {dermal }}=\frac{C \times S A \times C F \times A F \times A B F \times E F \times E D}{B W \times A T}
\end{aligned}
$$

In this study, the non-carcinogenic and carcinogenic health risk of toxic elements in the soil is given by Equation 11:

$$
\text { 11. } H Q=\sum \frac{A D D}{R f D}
$$

Where HQ (hazard quotient) is the non-carcinogenic risk factor of elements by each route (exposure rate), $\mathrm{ADD}$ is the average daily dose of the element by each of the three mentioned routes $(309 \mathrm{mg} / \mathrm{kg} /$ day $)$, and $\mathrm{RfD}$ is the daily reference dose that estimates the maximum risk in the human population exposed daily to toxic elements, considering sensitive groups (adults and children) [19]. The RfD values were taken from the US Department of Energy's Risk Assessment Information System (RAIS). There are no adverse effects on human health, provided that the acceptable average daily intake (ADD) is less than the daily reference dose. Otherwise, if ADD is higher than RfD, it may adversely affect human health. If $\mathrm{HQ}<1$, there is no adverse effect, but if $\mathrm{HQ}>1$, there might be an adverse effect on human health [20]. By summing the HQ in each route, the HI can be obtained to estimate the risk of all polluted elements according to Equation 12:

\section{2. $\mathrm{HI}=\sum_{\mathrm{i}=1}^{3} \mathrm{HQ}$}

Here, the HI calculated for all elements indicates the severity of undesirable effects by all routes of human exposure [21]. For $\mathrm{HI} \leq 1$, there are no apparent adverse health effects from toxic elements. However, for $\mathrm{HI}>1$, there are adverse health effects for the residential population [18]. The health risk assessment for carcinogenic toxic element exposures in adults and children was calculated for each of the three routes, namely ingestion, inhalation, and dermal contact, using Equation 13.

\section{3. $\mathrm{CR}=\sum \mathrm{ADD} \times \mathrm{SF}$}

Table 4. Characteristic values of potential ecological risk

\begin{tabular}{cccc}
\hline Ei Index & Risk per Element & Risk Index (RI) & Total Risk \\
\hline $\mathrm{Ei}<40$ & Low & $\mathrm{Rl}<150$ & Low \\
$40 \leq \mathrm{Ei}<80$ & Moderate & $150 \leq \mathrm{Rl}<300$ & Moderate \\
$80 \leq \mathrm{Ei}<160$ & Significant & $300 \leq \mathrm{Rl}<600$ & High \\
$160 \leq \mathrm{Ei}<320$ & High & $\mathrm{RI} \geq 600$ & Very High \\
$\mathrm{Ei} \geq 320$ & Very high & - & - \\
\hline
\end{tabular}


Table 5. Descriptive statistics of toxic element concentration in studied stations

\begin{tabular}{|c|c|c|c|c|c|c|c|}
\hline Element & $\mathrm{Cd}$ & As & $\mathrm{Cu}$ & $\mathrm{Zn}$ & $\mathbf{P b}$ & $\mathrm{Cr}$ & $\mathrm{Ni}$ \\
\hline Average & 7.68 & 0.168 & 2839.77 & 109.30 & 979.40 & 733.67 & 792.87 \\
\hline Middle & 7.52 & 0.14 & 852 & 102.50 & 653 & 702 & 836.50 \\
\hline Standard Deviation & 2.03 & 0.14 & 7424.02 & 28.53 & 809.50 & 438.63 & 444.79 \\
\hline Skewness & 0.54 & 4.90 & 3.75 & 0.528 & 2.14 & 0.418 & 0.219 \\
\hline Range & $3.12-45.36$ & $0.0-8.9$ & $33950-174$ & $48-186$ & $3740-181$ & $1634-114$ & $1721-105$ \\
\hline The Kolmogorov-Smirnov test & 0.20 & $-0.9 \mathrm{E} 1.2$ & -15 E 1.6 & 0.153 & 0.05 & 0.20 & 0.20 \\
\hline
\end{tabular}

$\mathrm{CR}$ is the carcinogenic risk in the above Equation, and $\mathrm{SF}$ is the carcinogenic slope factor ( $\mathrm{mg} / \mathrm{kg} /$ day). SF captures the assessed daily dose of pollutants during exposure to a person's growing risk of developing cancer. In general, according to the US Environmental Protection Agency, if the Carcinogenic Risk (CR) is less than $1 \times 10^{6}$ (the probability that one person in a million will develop cancer), the risk can be neglected. However, if the CR value is above $1 \times 10^{4}$, it is harmful and dangerous to human health. The CR value between $1 \times 10^{-6}$ and $1 \times 10^{-4}$ represents an acceptable risk that is under control [18].

\section{Results and Discussion}

Table 5 presents the descriptive statistics of toxic element concentration $(\mathrm{mg} / \mathrm{kg})$ in the studied stations of the soil surface of Arak. The skewness coefficient values of $\mathrm{Ni}, \mathrm{Cr}, \mathrm{Zn}$, and $\mathrm{Cd}$ are close to 0 , indicating the normal distribution of the elements. But, the skewness coefficient values of $\mathrm{Pb}$, $\mathrm{Cu}$, and $\mathrm{As}$ are exceptionally high, indicating the abnormal distribution of the elements. These findings are confirmed by the results obtained from the Kolmogorov-Smirnov test. Arsenic is less than 1, which shows its geogenic origin.
Other elements such as $\mathrm{Ni}, \mathrm{Cr}, \mathrm{Pb}, \mathrm{Zn}, \mathrm{Cu}$, and $\mathrm{Cd}$ have variance values greater than 1 , indicating the anthropogenic origin in the surface soils of Arak [22].

The high concentration of the elements is related to anthropogenic resources, such as several industries, machinery manufacturing, HEPCO (Heavy Equipment Production Company), urban traffic, car rubber wear, corrosion of the element parts of cars, and application of chemical fertilizers on agricultural lands. The descriptive statistics of the concentration of Potentially Toxic Elements (PTEs) in the collected surface soils of Arak are presented in Table 5. The range and average values of the studied PTEs were given as follows: $\mathrm{Pb}, 181-3740 \mathrm{mg} /$ kg (mean: 947.40); Zn, 48-586 mg/kg (mean: 290.50); $\mathrm{Cu}, 174-3950 \mathrm{mg} / \mathrm{kg}$ (mean: 2839.77); Ni, 105-1721 mg/ kg (mean: 792.87); As, 0.08-0.90 mg/kg (mean: 0.17); Cr, 114-1624 mg/kg (mean: 733.67); and Cd, 3.45-12.36 $\mathrm{mg} / \mathrm{kg}$ (mean: 7.68). The results revealed that the mean concentration of all studied PTEs in the study area was higher than the local baseline, Upper Continental Crust (UCC), world soil, Canadian, Dutch, and Chinese soil quality guidelines. However, this finding suggests the

Table 6. Average concentration of toxic elements $(\mathrm{mg} / \mathrm{kg})$ in Arak and other cities of the world

\begin{tabular}{|ccccccccc|}
\hline City /Country & $\mathbf{N i}$ & $\mathbf{C r}$ & $\mathbf{P b}$ & $\mathbf{Z n}$ & $\mathbf{C u}$ & As & $\mathbf{C d}$ & Reference \\
\hline Iran/Arak & 792.87 & 733.67 & 979.40 & 109.30 & 2839.77 & 0.17 & 7.68 & Present study \\
\hline Ottawa/Canada & 15 & 42 & 33 & 101 & 38 & 1 & 0.3 & {$[30]$} \\
\hline Tehran/Iran & 34.8 & 33.5 & 257.4 & 873.2 & 225.3 & - & 10.7 & {$[28]$} \\
\hline Xiangyang/China & 45.44 & 3715 & 80.92 & 114 & 69.11 & 27.13 & 4.24 & {$[24]$} \\
\hline $\begin{array}{c}\text { Ahvaz/Iran } \\
\text { Andhra Pradesh/ }\end{array}$ & 57 & 50 & 59 & 288 & 113 & 7 & 0.52 & {$[8]$} \\
\hline $\begin{array}{c}\text { India } \\
\text { World Soil }\end{array}$ & 24 & 67 & 27 & 70 & 38.9 & 6.83 & 0.41 & {$[29]$} \\
\hline \begin{tabular}{c} 
Field values in world \\
\hline
\end{tabular} & 50 & 70 & 35 & 90 & 30 & 6 & 0.35 & {$[25,26]$} \\
\hline
\end{tabular}


Table 7. The spearman correlation of toxic element concentrations $(\mathrm{mg} / \mathrm{kg})$ at the studied stations

\begin{tabular}{|c|c|c|c|c|c|c|c|}
\hline Element & $\mathrm{Ni}$ & $\mathrm{Cr}$ & $\mathrm{Pb}$ & $\mathrm{Zn}$ & $\mathrm{Cu}$ & As & $\mathrm{Cd}$ \\
\hline $\mathrm{Ni}$ & 1 & & & & & & \\
\hline $\mathrm{Cr}$ & $0.962 * *$ & 1 & & & & & \\
\hline $\mathrm{Pb}$ & $0.528 * *$ & $0.514^{* *}$ & 1 & & & & \\
\hline $\mathrm{Zn}$ & $0.410^{*}$ & $0.426 * *$ & 0.308 & 1 & & & \\
\hline $\mathrm{Cu}$ & $0.584 * *$ & $0.576 * *$ & $0.838^{* *}$ & $0.517^{* *}$ & 1 & & \\
\hline As & 0.067 & 0.087 & -0.111 & -0.102 & -0.253 & 1 & \\
\hline $\mathrm{Cd}$ & $0.462^{*}$ & $0.488 * *$ & 0.300 & $0.519 * *$ & 0.205 & 0.129 & 1 \\
\hline
\end{tabular}

${ }^{*}$ Correlation at $5 \%$ level, ${ }^{* *}$ Correlation at $1 \%$ level.

anthropogenic source of the PTEs, such as vehicle traffic emissions, industrial inputs, construction, and steel industry $[22,23]$. The Kolmogorov-Smirnov results showed that the concentration of the studied PTEs had a nonnormal distribution behavior (Sig. $>0.05$ ), except for As (Sig. $<0.05$ ). The skewness values of the studied PTEs ranging from 1.54 to 21.36 were greater than 0 , indicating the non-normal distribution. Also, the mean value of the studied PTEs is higher than the median value. These findings also imply the existence of highly contaminated areas and polluted hotspots that extend throughout the study area. According to the coefficient of variance $(\mathrm{CV})$, the studied PTEs indicate that the elements with $\mathrm{CV}$ values higher than 0.5 include $\mathrm{Ni}, \mathrm{Cr}, \mathrm{Pb}, \mathrm{Cu}, \mathrm{As}$, and $\mathrm{Cd}(\mathrm{CV}<0.5)$ [24]. The elements with a lower $\mathrm{CV}$ show the limited geogenic sources of the PTEs and the entry points of the elements in the soil. In addition, the elements with a higher CV indicate a mixture of geogenic and anthropogenic sources [8]. Table 6 presents the mean concentration $(\mathrm{mg} / \mathrm{kg})$ of the studied PTEs in relation to other selected metropolitan areas in the world, local background, and baseline values in the study area. All studied PTEs have greater values compared to the world soil and baseline values. Accordingly, the concentrations of $\mathrm{Ni}, \mathrm{Cr}, \mathrm{Pb}, \mathrm{Zn}, \mathrm{Cu}, \mathrm{As}$, and $\mathrm{Cd}$ in the soil samples of Arak are 33, 10, 36, 1.55, 72, 1.58, and 18.5 times higher than in the world soils, respectively $[25,26]$. Also, the values of PTEs in the studied samples are 15.8, 10.4, 27, $1.21,94.1 .58$ and 21.9 times the background values in the world, respectively [27]. The concentrations of $\mathrm{Ni}$, $\mathrm{Cr}, \mathrm{Pb}$, and $\mathrm{Cu}$ in the urban soils of Arak are 22.7, 21.8, 3.8, and 12.6 times higher than those in Tehran (Iran), respectively, while the concentrations of $\mathrm{Zn}$ and $\mathrm{Cd}$ are lower than those in Tehran [28]. The concentrations (mg/ $\mathrm{kg})$ of $\mathrm{Ni}(17.6,13.9), \mathrm{Cr}(1.02,14), \mathrm{Pb}(12,17), \mathrm{Cu}(41$, $25)$, and $\mathrm{Cd}(1.75,14)$ are lower than the corresponding values recommended. In contrast, the values of $\mathrm{Zn}$ and As in the sampled soils are lower than those in Ahvaz (Iran) [8] and Xiangyang (China) [24] respectively. The mean concentration of the studied PTEs in the surface soil of Arak is estimated to be higher than that Andhra Pradesh (India) [29] and in Ottawa (Canada) [30].

The spatial distribution pattern of toxic element concentration can help identify areas with low, medium, and high pollution sources and hotspots. As shown in Figure 2, the orange and red colors on the maps indicate the high concentration of the studied toxic elements located in the industrial zone of Arak, as classified in Figure 1. The distribution of As concentration was different from other toxic elements studied and was less polluted. The map of the spatial distribution of $\mathrm{Pb}$ concentration shows the high concentration of $\mathrm{Pb}$ in areas with high traffic, which is one of the main sources of gasoline combustion by vehicles. The spatial distribution of $\mathrm{Cd}$ concentration is higher in areas where industries are located, especially HEPCO and the aluminum industry. The spatial distribution of $\mathrm{Cu}$ and $\mathrm{Zn}$ concentrations shows that an increase in $\mathrm{Cu}$ and $\mathrm{Zn}$ concentrations was

Table 8. Descriptive statistics of Nemerow Integrated Pollution Index (NIPI) at stations under study

\begin{tabular}{cccccccc}
\hline \multicolumn{1}{c}{ NIPI } & \multicolumn{7}{c}{ Case No. } \\
\hline Min & Average & Max & No pollution & Risk warning & Low Pollution & $\begin{array}{c}\text { Moderate level } \\
\text { Pollution }\end{array}$ & $\begin{array}{c}\text { High-level } \\
\text { pollution }\end{array}$ \\
\hline 24.58 & 72.14 & 408.61 & 0 & 0 & 0 & 0 & $30(100 \%)$ \\
\hline
\end{tabular}



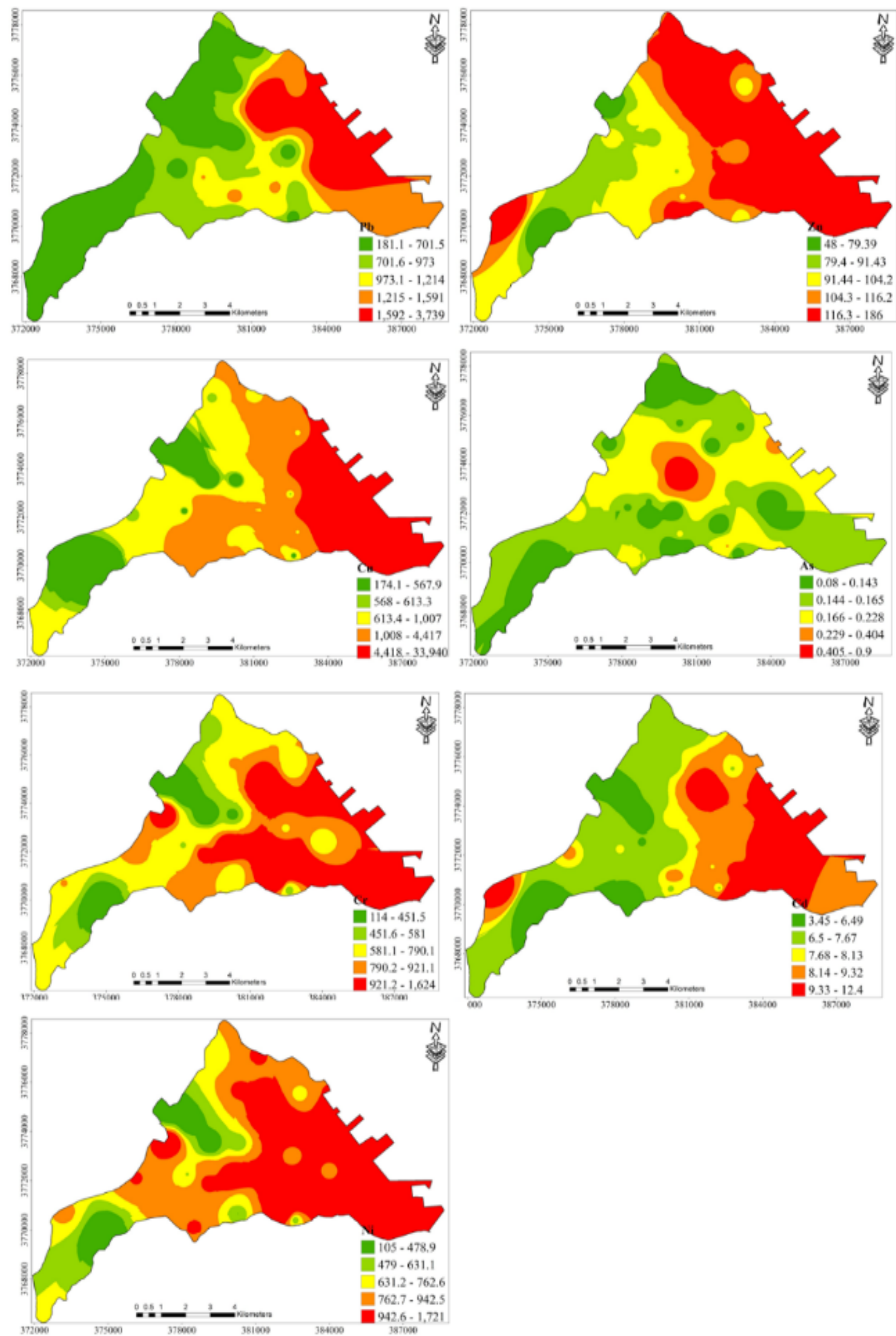

Figure 2. Spatial distribution pattern of toxic element concentrations in Arak 


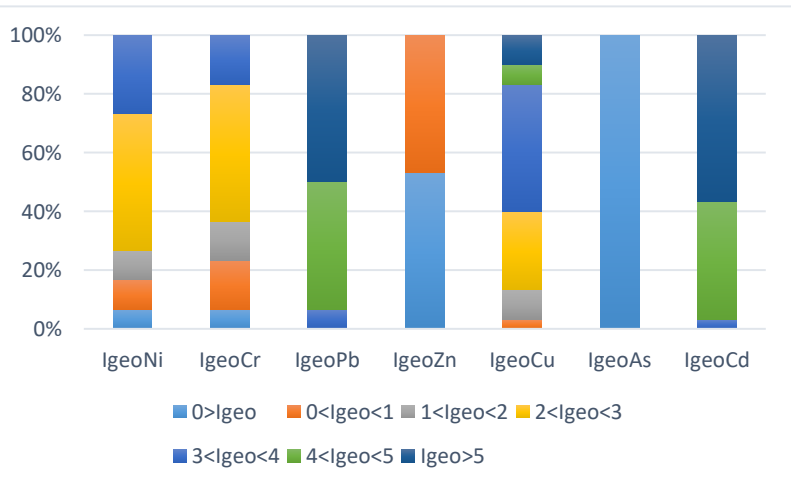

Figure 3. Geo-accumulation Index (Igeo) at stations understudy

observed when approaching agricultural areas. In addition, a high concentration of $\mathrm{Cu}$ was observed along the roads. The maximum concentration of $\mathrm{Zn}$ is seen in the areas of high traffic where the highest corrosion rate of elements occurs. The abrasion of rubber and burning of waste fuels can increase the element in the surface soils of Arak. The map of the spatial distribution of $\mathrm{Ni}$ concentration indicates the high concentration of the element in most of the surface soils in Arak. The areas polluted with Ni have a high traffic volume and are located close to gas stations, industries, and surface soils studied near the accumulation of construction waste. Low concentrations of $\mathrm{Ni}$ can be considered as surface soils studied around residential areas in Arak. Also, the spatial distribution map of $\mathrm{Cr}$ concentration indicates the high concentration of $\mathrm{Cr}$ in dense urban areas.

Table 7 presents the Spearman correlation analyses between the toxic elements in the studied soil samples, which is significant. The correlation coefficient between the toxic elements showed that $\mathrm{Ni}$ had a positive and significant correlation at $0.01 \%$ level with $\mathrm{Cr}, \mathrm{Pb}$, and $\mathrm{Cu}$ and at $0.05 \%$ level with $\mathrm{Zn}$ and $\mathrm{Cd}$. Also, $\mathrm{Cr}$ had a positive and significant correlation with $\mathrm{Pb}, \mathrm{Zn}, \mathrm{Cu}$, and $\mathrm{Cd}$ at 0.01 level. The $\mathrm{Pb}-\mathrm{Zn}$ and $\mathrm{Zn}-\mathrm{Cd}$ have a positive and significant correlation at $0.01 \%$ level. The correlation between the elements indicates that the release of toxic elements in the surface soils of Arak is due to the same anthropogenic sources. In addition, Arsenic did not correlate with other toxic elements, $\mathrm{Cd}$ did not correlate with $\mathrm{Cu}$, and $\mathrm{Pb}$ did not correlate with $\mathrm{Zn}$, indicating different sources of toxic element release in the surface soils of Arak [8].

Figure 3 shows the percentage of Igeo of toxic elements at 30 stations. Accordingly, the Igeo index ranges from -0.26 (unpolluted) to 3.77 (strongly polluted) for $\mathrm{Ni},-0.42$ (unpolluted) to 3.41 (strongly polluted) for $\mathrm{Cr}$, 3.11 (strongly polluted) to 7.48 (extremely polluted) for $\mathrm{Pb},-1.13$ (unpolluted) to 82.820 (unpolluted to mod- erately polluted) for $\mathrm{Zn}, 0.95$ (unpolluted to moderately polluted) to 8.56 (extremely polluted) for $\mathrm{Cu},-5.08$ (unpolluted) to -1.58 (unpolluted) for As, and 3.94 (strongly polluted) to 5.78 (extremely polluted) for $\mathrm{Cd}$. Based on this index for the elements, As and $\mathrm{Zn}$ with mean values of -4.20 and 0.008 , respectively, and their variations, the surface soils of Arak are unpolluted with respect to the two elements. For other elements, the mean Igeo index values were 2.33 for $\mathrm{Ni}, 1.92$ for $\mathrm{Cr}, 5.19$ for $\mathrm{Pb}, 3.37$ for $\mathrm{Cu}$, and 5.04 for $\mathrm{Cd}$. Based on the Igeo index classification of pollution intensity presented in Table 1, the study area has moderate to strong pollution in terms of $\mathrm{Ni}$. Chromium has moderate pollution, $\mathrm{Pb}$ is extremely polluted, $\mathrm{Cu}$ has strong pollution, and $\mathrm{Cd}$ is extremely polluted. Accordingly, the highest value of the Igeo index was for $\mathrm{Pb}$ and the lowest value for As. The pollution rate for toxic elements based on the Igeo index was in the order of $\mathrm{Pb}>\mathrm{Cd}>\mathrm{Cu}>\mathrm{Ni}>\mathrm{Cr}>\mathrm{Zn}>$ As.

Table 8 presents the calculation and investigation of pollution level for NIPI of toxic elements at 30 studied stations in terms of descriptive statistics and the number of samples for pollution index classification. The results of the NIPI index showed that $100 \%$ of surface soil samples in the study area had a high level of pollution. On the other hand, the high level of toxic element pollution in Arak indicates the presence of strong element pollution and the anthropogenic source of the toxic elements in the surface soils of Arak. These elements, especially lead, can affect the ecological performance at very high concentrations [2].

The Spearman correlation coefficient indicated a similar relationship among the toxic elements, namely, $\mathrm{Pb}$, $\mathrm{Cr}, \mathrm{Cd}, \mathrm{Ni}, \mathrm{Cu}$, and $\mathrm{Zn}$, with respect to pollution sources. The surface soils of Arak are free from pollution in terms of As and $\mathrm{Zn}$ based on the Igeo pollution index. Also, Ni shows a moderate to strong pollution level, $\mathrm{Cr}$ is moderately polluted, $\mathrm{Cu}$ shows strong pollution, and 
$\mathrm{Pb}$ and $\mathrm{Cd}$ are extremely polluted in terms of the Igeo. The NIPI index indicated that $100 \%$ of the surface soil samples had a high pollution level. The TEF values of toxic elements of $\mathrm{Ni}, \mathrm{Cr}, \mathrm{Pb}$, and $\mathrm{Cu}$ were higher than other elements. This finding confirms that these elements have geochemical behavior and share the same anthropogenic sources in terms of pollution. This finding suggests that the anthropogenic sources of the elements are due to the presence of Iran Chemical Manufacturing Company, machine manufacturing industry, aluminum rolling, HEPCO, agricultural lands, and urban traffic. Thus, there is concern about contamination of the surface soils regarding the elements in the surface soils of Arak city. Therefore, according to Table 4, if Ei $<40$ and $\mathrm{RI}<150$, the Potential Ecological Risk (PER) index is low; if $40 \leq \mathrm{Ei}<80$ and $150 \leq \mathrm{RI}<300$, the PER index is moderate; if $80 \leq \mathrm{Ei}<160$ and $300 \leq \mathrm{RI}<600$, the PER index is high, and if $160 \leq \mathrm{Ei}<320$ and $\mathrm{RI} \geq 600$, the PER index is extremely high. The PER for the elements indicates a high and extremely high-risk level. The noncarcinogenic Health Assessment (HI) results of the toxic elements showed that $\mathrm{Cr}$ and $\mathrm{Pb}$ have non-carcinogenic effects on children. For all elements, the HI index values were higher for children than for adults. Also, the results of the toxic elements' carcinogenic health risk assessment (CR) showed that Cr's carcinogenic risk for children with an average value of 0.001 and for adults with an average value of 04-3.81E poses a serious health threat to both children and adults.

\section{Conclusion}

The results showed that the mean concentration values of all toxic elements except arsenic were higher than the world's soil and field values. Compared with other cities in the world, the mean concentrations of toxic elements of $\mathrm{Ni}, \mathrm{Cr}, \mathrm{Pb}$, and $\mathrm{Cu}$ were higher than those in all the mentioned cities. Also, the concentration of As was lower than all the cities under study. Cadmium, with a value of 68.7, is higher in all the cities studied except Tehran, with a value of 7.10. Except for arsenic, the sources of PTEs, were mainly the industrial hubs and manufacturing industries located in the study area. Higher values of reducible binding for $\mathrm{Pb}, \mathrm{Cr}$, and $\mathrm{Zn}$, and a considerable percentage of $\mathrm{Ni}, \mathrm{Cu}$ and, $\mathrm{Cd}$, demonstrated that the primary sources of the studied PTEs (except Arsenic) in the study area were both anthropogenic and geogenic.

\section{Ethical Considerations}

Compliance with ethical guidelines

\section{Funding}

This research did not receive any grant from funding agencies in the public, commercial, or non-profit sectors.

\section{Authors' contributions}

All authors equally contributed to preparing this article.

\section{Conflict of interest}

The authors declared no conflict of interest.

\section{Acknowledgments}

The authors would like to acknowledge the Geochemical Laboratory of Islamic Azad University of Ahvaz for providing Laboratory space and facilities.

\section{References}

[1] Wuana RA, Okieimen FE. Heavy metals in contaminated soils: A review of sources, chemistry, risks and best available strategies for remediation. int. sch. res. notices. 2011; 2011:1-20. [DOI:10.5402/2011/402647]

[2] Nazarpour A, Ghanavati N, Babaenejad T. [Evaluation of the level of pollution and potential ecological risk of some heavy metals in surface soils in the Ahvaz oil-field (Persian)]. Iran J Health Environ. 2017; 10(3):391-400. https:/ ijhe.tums. ac.ir/browse.php?a_id=5924\&sid=1\&slc_lang=en

[3] Sidhu GPS. Heavy metal toxicity in soils: Sources, remediation technologies and challenges. Adv Plants Agric Res. 2016; 5(1):445-6. [DOI:10.15406/apar.2016.05.00166]

[4] Moghtaderi T, Mahmoudi SH, Shakeri A, Masihabadi MH [Contamination evaluation, health and ecological risk index assessment of potential toxic elements in the surface soils (case study: central part of Bandar Abbas county) (Persian)]. J Water Soil Resour Conserv. 2019; 8(4):51-65. [DOI:20.1001.1.2 2517480.1398.8.4.4.1]

[5] Dolezalova Weissmannova H, Pavlovsky J, Chovanec P. Heavy metal contaminations of urban soils in Ostrava, Czech Republic: Assessment of metal pollution and using principal component analysis. Int J Environ Res. 2015; 9(2):683-96. [DOI:10.22059/IJER.2015.943]

[6] Zhuo H, Wang X, Liu H, Fu S, Song H, Ren L. Source analysis and risk assessment of heavy metals in development zones: A case study in Rizhao, China. Environ Geochem Health. 2020; 42(1):135-46. [DOI:10.1007/s10653-019-00313-7] [PMID]

[7] Ghanavati N, Nazarpour A. [Environmental investigation of heavy metals concentration in Ahvaz city street dust, by using Geographical Information Systems (GIS) (Persian)]. J Environ Stud. 2018; 44(3):393-410. [DOI:10.22059/JES.2019.213132.1007285]

All ethical principles were considered in this article. 
[8] Ghanavati N, Nazarpour A, Watts MJ. Status, source, ecological and health risk assessment of toxic metals and Polycyclic Aromatic Hydrocarbons (PAHs) in street dust of Abadan, Iran. Catena. 2019; 177:246-59. [DOI:10.1016/j.catena.2019.02.022]

[9] Muller G. Index of geoaccumulation in sediments of the Rhine River. J Geol. 1969; 2: 108-18. https:/ / www.scienceopen.com/ document?vid=4b875795-5729-4c05-9813-64951e2ca488

[10] Benhaddya ML, Boukhelkhal A, Halis Y, Hadjel M. Human health risks associated with metals from urban soil and road dust in an oilfield area of Southeastern Algeria. Arch Environ Contam Toxicol. 2016; 70(3):556-71. [DOI:10.1007/s00244-0150244-6] [PMID]

[11] Jefferson Lab. It's elemental-the periodic table of elements. Archived from the original on 29 April 2007. Retrieved 2007-0414. https://education.jlab.org/itselemental/

[12] Panahpour E. [The study on the level of pollution and spatial distribution of concentrations of heavy metals $(\mathrm{Cr}, \mathrm{Ni}, \mathrm{Cu}, \mathrm{Pb}$ and $\mathrm{Zn}$ ) in the Industrial City of Mah-Shahr (Persian)]. J Nat Environ. 2018; 71(3):399-412. [DOI: 10.22059/JNE.2018.220690.1277]

[13] Lu X, Wang L, Lei K, Huang J, Zhai Y. Contamination assessment of copper, lead, zinc, manganese and nickel in street dust of Baoji, NW China. J Hazard Mater. 2009; 161(2/3):1058-62. [DOI:10.1016/j.jhazmat.2008.04.052] [PMID]

[14] Wu S, Peng S, Zhang X, Wu D, Luo W, Zhang T, et al. Levels and health risk assessments of heavy metals in urban soils in Dongguan, China. J Geochem Explor. 2015; 148:71-8. [DOI:10.1016/j.gexplo.2014.08.009]

[15] Yang Z, Lu W, Long Y, Bao X, Yang Q. Assessment of heavy metals contamination in urban topsoil from Changchun City, China. J Geochem Explor. 2011; 108(1):27-38. [DOI:10.1016/j. gexplo.2010.09.006]

[16] Yu L, Zhang B, Zhang SQ. Heavy metal elements pollution evaluation on the ecological environment of the Sanjiang Plain based on GIS. Chin J Soil Sci. 2004; 35(5):529-32. https:/ / scholar. google.com/scholar?hl=en\&as_sdt=0\%2C5\&q

[17] Hakanson L. An ecological risk index for aquatic pollution control. A sedimentological approach. Water Res. 1980; 14(8):975-1001. [DOI:10.1016/0043-1354(80)90143-8]

[18] Bennett PM, Jepson PD, Law RJ, Jones BR, Kuiken T, Baker JR. Exposure to heavy metals and infectious disease mortality in harbour porpoises from England and Wales. Environ pollut. 2001; 112(1):33-40. [DOI:10.1016/S0269-7491(00)00105-6]

[19] Man YB, Sun XL, Zhao YG, Lopez BN, Chung SS, Wu SC, et al. Health risk assessment of abandoned 1150 agricultural soils based on heavy metal contents in Hong Kong, the world's most populated city. Environ Int. 2010; 36(6):570-6. [DOI:10.1016/j. envint.2010.04.014] [PMID]

[20] Kurtz JC, Jackson LE, Fisher WS. Strategies for evaluating indicators based on guidelines from the Environmental Protection Agency's Office of Research and Development. Ecol Indic. 2001; 1(1):49-60 [DOI:10.1016/S1470-160X(01)00004-8]

[21] Wei X, Gao B, Wang P, Zhou H, Lu J. Pollution characteristics and health risk assessment of heavy metals in street dusts from different functional areas in Beijing, China. Ecotoxicol Environ Saf. 2015; 112:186-92. [DOI:10.1016/j.ecoenv.2014.11.005] [PMID]
[22] Babaei H, Ghanavati N, Nazarpour A. [Contamination level of mercury in the street dust of Ahvaz city and its spatial distribution (Persian)]. J Water Soil Sci. 2018; 22(3):249-59 [DOI:10.29252/jstnar.22.3.249]

[23] Sadeghdoust F, Ghanavati N, Nazarpour A, Babaenejad T, Watts MJ. Hazard, ecological, and human health risk assessment of heavy metals in street dust in Dezful, Iran. Arab J Geosci. 2020; 13:881. [DOI:10.1007/s12517-020-05915-5]

[24] Wu W, Wu P, Yang F, Sun DL, Zhang DX, Zhou YK. Assessment of heavy metal pollution and human health risks in urban soils around an electronics manufacturing facility. Sci Total Environ. 2018; 630:53-61. [DOI:10.1016/j.scitotenv.2018.02.183]

[25] Kabata-Pendias A. Trace elements in soils and plants. Boca Raton: CRC Press; 2010. [DOI:10.1201/b10158]

[26] Kabata-Pendias A. Trace elements in soils and plants. $3^{\text {rd }}$ ed. Boca Raton: CRC Press; 2000. [DOI:10.1201/9781420039900]

[27] Du Y, Gao B, Zhou H, Ju X, Hao H, Yin S. Health risk assessment of heavy metals in road dusts in urban parks of Beijing, China. Procedia Environ Sci. 2013; 18:299-309. [DOI:10.1016/j. proenv.2013.04.039]

[28] Saeedi M, Li LY, Salmanzadeh M. Heavy metals and polycyclic aromatic hydrocarbons: Pollution and ecological risk assessment in street dust of Tehran. J Hazard Mater. 2012; 227-228:9-17. [DOI:10.1016/j.jhazmat.2012.04.047] [PMID]

[29] Das Sharma S. Risk assessment and mitigation measures on the heavy metal polluted water and sediment of the Kolleru Lake in Andhra Pradesh, India. Pollution. 2019; 5(1):161 78. [DOI:10.22059/POLL.2018.263546.493]

[30] Rasmussen PE, Subramanian KS, Jessiman BJ. A multielement profile of house dust in relation to exterior dust and soils in the city of Ottawa, Canada. Sci Total Environ. 2001; 267(1/3):125-40. [DOI:10.1016/S0048-9697(00)00775-0] [PMID] 
This Page Intentionally Left Blank 